\title{
Effect of surface humus on water infiltration and redistribution in beech forest stands with different density
}

\author{
Marián Homolák*, Viliam Pichler, Erika Gömöryová, Juraj Bebej \\ Technical University in Zvolen, Faculty of Forestry, T. G. Masaryka 24, SK-960 53 Zvolen, Slovak Republic
}

\begin{abstract}
The aim of the paper is to demonstrate how the beech surface humus form and forest density affect the infiltration and redistribution of rainwater into the soil matrix. Beech as the most-abundant tree species in Slovakia has a tendency to form a compact humus layer with specific structure, leading to a reduction in the soil surface infiltration area and a significant influence on the preferential flow generation. The research was carried out in beech forests with different forest stand density in the Vtáčnik Mountain (Central Slovakia). The maximal infiltration surface area $35.11 \pm 6.58 \%$ of sand surface infiltration area was reached at the plot $\mathrm{A}(0.8)$. The minimal infiltration surface area was reached at the plot B $(0.8)$ and was $19.45 \pm 2.52 \%$. Statistical tests confirmed a significant effect of the forest stand density on the surface infiltration area $(p=0.05)$ and number of infiltration inputs $(p=0.05)$. The results show a statistically significant influence of surface humus form and stand density on infiltration and redistribution of rainwater into the soil matrix. The influence results in water flow changes from matrix flow to preferential flow and fingering. As a consequence deeper infiltration of water and solutions, e. g. dissolved organic carbon, to deeper soil layers is observed.
\end{abstract}

Key words: surface humus; beech forests; infiltration; water regime

Editor: Zuzana Sitková

\section{Introduction}

Surface humus plays a key role in mediating interactions between the atmosphere and soil. Its quantity, composition and origin of the individual components, internal structure and spatial distribution affect mainly water, heat, air retention and accumulation regime. Along with filtration, buffering, transformation and anti-erosion function it defines the entire portfolio of ecological and environmental functions of soil.

Research on a surface humus in forest ecosystems has been mainly focused on the quantitative characteristics (e.g. Ottmar \& Andreu 2007), to a lesser extent on its quality properties, especially regarding the origin of the individual components, and the causes and impact of its various forms on bulk density and porosity (e.g. Ogée \& Brunet 2002; Matthews 2005). Later the research focused on the internal and spatial surface humus structure, the heterogeneous distribution in space and the resulting effect on important processes in forest ecosystems, such as the infiltration of water into the soil (Campbell et al. 2004). Many studies are also oriented on spatial and temporal variability of interception of surface humus (e.g. Gerrits et al. 2010) and percolation of rainfall through humus layer (e.g. Dunkerley 2015) but without direct measurement of soil surface area affected by percolated water. Surface humus form and thickness ultimately affect the entire range of environmental functions of soil not only in terms of soil water redistribution, but also e.g. the release of dissolved soil organic carbon and its accumulation in deeper soil layers, which is directly relevant to the process of infiltration (Qualls et al. 2002). Infiltration into forest soil is affected by soil cracks, soil texture and structure, root system and especially by surface humus which reduces destructive effects of raindrops on soil surface, reducing the water level formation on a soil surface, which allows the outflow of air from pore space and the increase of infiltration intensity. In contrast, the layer of undecomposed leaves, especially when they are compressed by snow or rain, can reduce penetration of rainwater into the soil and support the surface runoff (Valtýni 1985). However, according to Kantor \& Šach (2007) surface runoff in beech forests during growing season in 2005 and 2006 on approximately $30 \%$ slope reached only $0.5 \%$ of annual rainfall. Very low surface runoff was found also by Jankov \& Gubka (2013). In beech forest on $65 \%$ slope they found average surface runoff $1.2 \%$ of annual rainfall. Forest soils are character- 
ised by very low compaction with relatively high porosity and water conductivity and contribute to the reduction of surface runoff and minimise the peak of storm flows (e.g. Hegg et al. 2004; Hümann et al. 2011; Robinson et al. 2003)

Walsh \& Voigt (1977), Ponge (1999, 2002), Ampe \& Langohr (2003) highlighted the impact of litter on geomorphological and hydrological processes in forest soils. Walsh \& Voigt (1977) investigated the potential water retention capacity of beech litter compared with pine litter. The quotient of mean retention capacity is 0.87 at beech litter and 0.54 at pine needle. That means $1 \mathrm{~g}$ of beech litter can absorb $0.87 \mathrm{~g}$ of water. In addition, in the thick layer of litter, especially in beech forests, it was observed tendency of water flow in a temporal concentrated paths which supported generation of funnel flow into the soil matrix. Following this process significant part of surface humus is excluded from the retention process, and therefore water retention is less than expected (Walsh \& Voigt 1977). According to Krečmer (1975) surface humus in pine forests can retain up to $32 \%$ of precipitation.

Surface humus thickness is influenced by internal processes within the forest ecosystem itself such as downslope transport (Steart et al. 2006; Abe et al. 2009) on the one hand, and external influences, mainly due to the changes in the forest density (e.g. natural disturbances or management activities), on the other hand. Reduction of forest stand density leads to faster decomposition and mineralisation of surface humus, which results in changes of surface humus form and its thickness. The aim of this work was to find out how the surface humus in beech forest with different stand density contribute to the percolation of water into the soil and how surface humus properties contribute to the reduction of soil surface infiltration area.

\section{Material and methods}

The series of plots were established in the Vtáčnik Mountain (48 37'32"N, $\left.18^{\circ} 38^{\prime} 49^{\prime \prime} \mathrm{E}\right)$ (Central Slovakia) in the European beech (Fagus sylvatica L.) forests. It falls into a cool mountainous and humid region (Lapin et al. 2002) with average annual temperature $3.0^{\circ} \mathrm{C}$, and the annual precipitation amount $950 \mathrm{~mm}$. The soils are classified as Fulvic Andosols (WRB 2007) developed from andesite slope deposits. The texture of the soil represents silty loam.

\subsection{Description of the experimental plots}

Samples of surface humus for laboratory tracer experiment were taken from four research plots with similar ecological conditions. All four plots have the same SEE exposure, inclination $10^{\circ}$, altitude $1,130-1,160 \mathrm{~m}$ a. s. l. Beech represents $100 \%$ in the stand composition.
Three plots are located in the beech forest with full forest stand density, and one is located in the beech forest with reduced stand density (Fig. 1):

Plot A (0.8): located in the beech forest with dense regeneration in the understorey (the height of regeneration is appr. $70 \mathrm{~cm}$ ), stand density 0.8 , stand age 130 years, humus form moder;

Plot B (0.8): located in the beech forest without regeneration, stand density 0.8 , stand age 110 years, humus form moder;

Plot C (1.0): located in the young beech forest, stand density 1.0 , stand age 45 years, humus form moder;

Plot D (0.4): located in the beech forest with reduced stand density, stand density 0.4 , stand age 90 years, humus form mull.

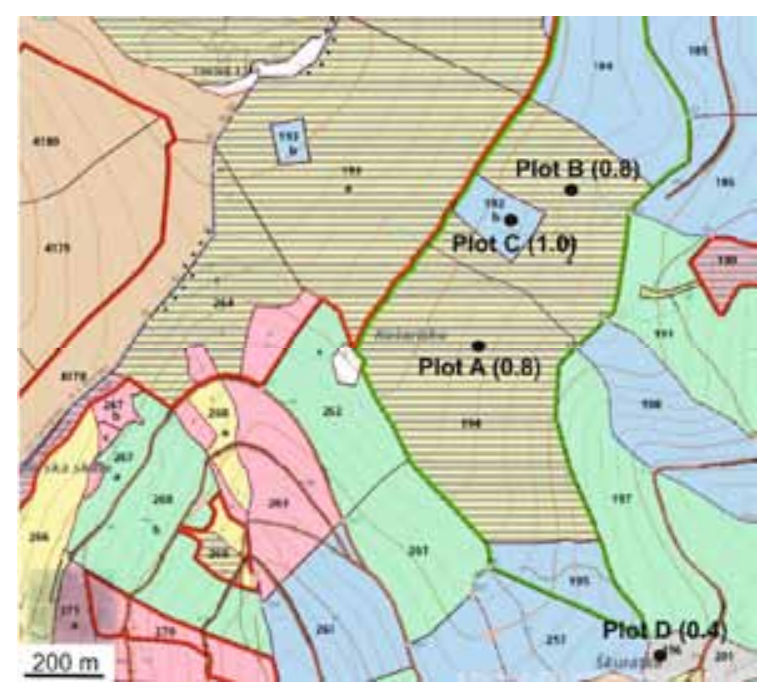

Fig. 1. Localization of experimental plots in central part of Vtáčnik Mts. (http://gis.nlcsk.org/lgis/, 2017).

\subsection{Infiltration experiment}

Infiltration experiment was performed on a series of surface humus samples with dimension $50 \times 35 \mathrm{~cm}$ in triplicate from each experimental plot (in duplicate in case of forest with reduced stand density). The thickness of the surface humus samples range between 5 $6 \mathrm{~cm}$. In total, 11 surface humus samples were taken for the laboratory analyses. Samples of surface humus from plots with full stand density were taken in autumn 2005 (experimental plots A (0.8), B (0.8) and C (1.0)), samples from plot with reduced stand density in autumn 2007 (experimental plot D (0.4)). In the laboratory, samples of the surface humus were placed on a wire sieve above the white sand. To each sample, a solution of Brilliant Blue FCF dye tracer was applied with concentration $10 \mathrm{~g} \mathrm{~L}^{-1}$ and in an amount of $2,550 \mathrm{ml}$, which is the equivalent of $15 \mathrm{~mm}$ rainfall. Application of the dye tracer solution consisted of 19 intervals, each lasting 10 minutes, during which the solution of about $135 \mathrm{ml}$ (approx. $0.8 \mathrm{~mm}$ of rainfall) was applied to the surface humus. The dye tracer solution percolated through the surface humus layer and infiltrated into the white sand column. After every solute 
application the surface humus samples were removed for a short time and the sand surface was photographed.

The sand surface pictures were analysed using the Dyeye software package (developed by Department of Agronomy, Iowa State University, Ames, IA), acting at the optimization of visual colour differences (Ewing \& Horton 1999), which allowed to select areas affected or not affected by dye solution. After that, the colour distribution histogram in each pixel was obtained using Image J software package. For the blue colour, colour range 160 -180 at 256 colour spectrum was used. The infiltration surface area represents the number of blue pixels in each application interval. In addition to the percentage of infiltration area the number of infiltration inputs in each pictures was detected. The number of infiltration inputs was obtained by counting of blue spots on sand surface at each picture. During the infiltration tracer experiment, a total of 209 pictures (after 19 pictures per area) were obtained that display the infiltration surface area and number of infiltration inputs related to particular simulating cumulative precipitation. Surface humus samples were cut at $5 \mathrm{~cm}$ intervals at the end of infiltration test and picture of each cut was taken. These images were used for assessing the degree of the influence of the internal structure of humus for the regulation of water infiltration into the soil (Fig. 2).
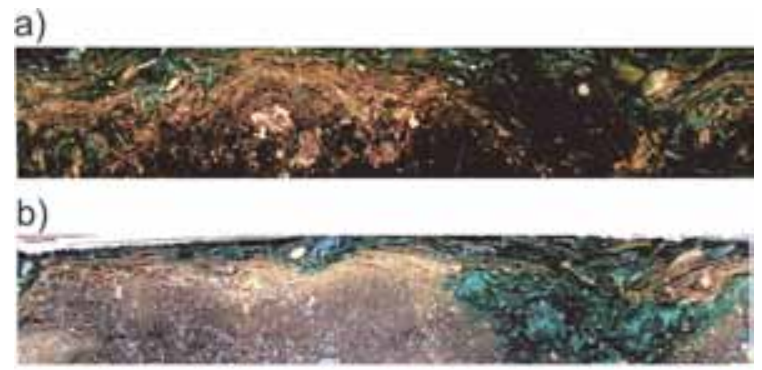

c)

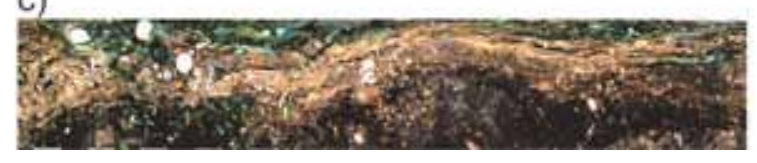

Fig. 2. Surface humus after application dye tracer (Brilliant Blue FCF) solution at the plot A (0.8) (a), plot B (0.8) (b) and plot C (1.0) (c).

\subsection{Statistical analyses}

The effect of different forest stand density on the cumulative infiltration on surface area and number of infiltration inputs were tested by Analyses of Covariance (Sokal \& Rohlf 1995). Subsequently, differences between separate forest stands were tested using Tukey's HSD post-hoc test (Tukey 1949). All statistical analyses were performed using STATISTICA 12 (StatSoft, Inc., Tulsa, USA) software package.

\section{Results}

Increase in the infiltration surface area is affected by the thickness of sand column placed under the each surface humus sample. It is expected that after reaching the bottom of the sand column the additional infiltrating water is distributed more laterally which causes the increase of infiltration surface area and the decrease of a number of infiltration inputs. Based on this we assumed that the maximal infiltration surface area affected by surface humus properties is reached when the number of infiltration inputs reaches local maximum and starts to decrease. The distribution of number of infiltration inputs and infiltration surface area are shown in the Fig. 3 and 4 , respectively.

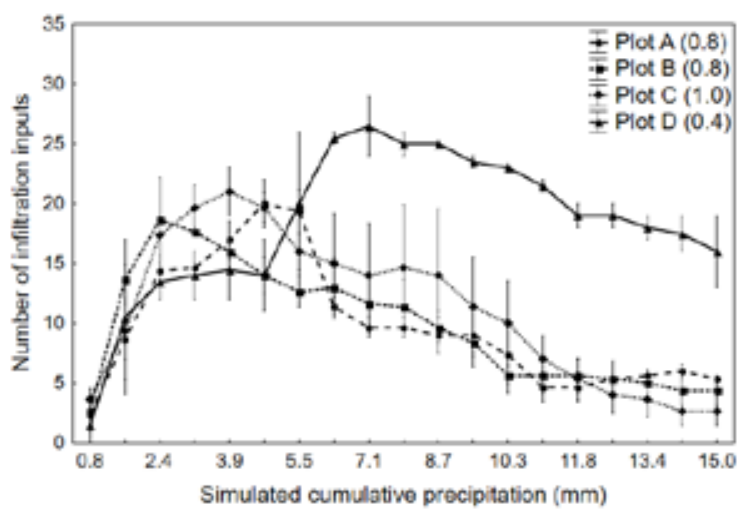

Fig. 3. The distribution of infiltration inputs with increasing cumulative precipitation at plots with different stand density.

Number of infiltration inputs at the plot A (0.8) increases to the value of $2.4 \mathrm{~mm}$ cumulative precipitation, at a level of $3.2 \mathrm{~mm}$ new infiltration inputs are activated and the maximum number of inputs is achieved at a level of $4.7 \mathrm{~mm}$ simulating cumulative precipitation. Plot B (0.8) shows the steepest increase in number of infiltration inputs, with a maximum value achieved even in $2.4 \mathrm{~mm}$ simulating cumulative precipitation. Interesting fact is that at this low value of simulated cumulative precipitation the infiltration surface area reaches the highest value of all plots. Number of infiltration inputs at the plot $\mathrm{C}$ (1.0) reaches its maximum value at $3.9 \mathrm{~mm}$ simulated cumulative precipitation. This value is also the highest value of number of infiltration inputs of all plots with full stand density. The maximal number of infiltration inputs of all beech plots was reached at the plot D (0.4). The number of infiltration inputs is increasing to the value $2.4 \mathrm{~mm}$ of simulated precipitation and remained relatively constant. At the value $4.7 \mathrm{~mm}$ of simulated precipitation new infiltration inputs were activated and the maximum was reached at the value $7.1 \mathrm{~mm}$ of simulated cumulative precipitation.

Based on above mentioned assumption the maximal infiltration surface area at the plot A $(0.8)$ was reached at $4.7 \mathrm{~mm}$ of the simulated precipitation what corresponds with $35.11 \pm 6.58 \%$ of sand surface infiltration area. This value of infiltration surface area was the high- 
est value of all beech forest plots. The minimal infiltration surface area was reached at the plot B (0.8) and was $19.45 \pm 2.52 \%$. This value was also reached at the lowest simulated precipitation $(2.4 \mathrm{~mm})$ of all studied plots. At the plot $\mathrm{C}(0.8)$ the infiltration surface area was $31.92 \pm$ $1.81 \%$ and was reached at $3.9 \mathrm{~mm}$ of simulated precipitation. At the plot D (0.4) the infiltration surface area was reached at the highest value of simulated precipitation $(7.1 \mathrm{~mm})$ and was $28.48 \pm 1.67 \%$.

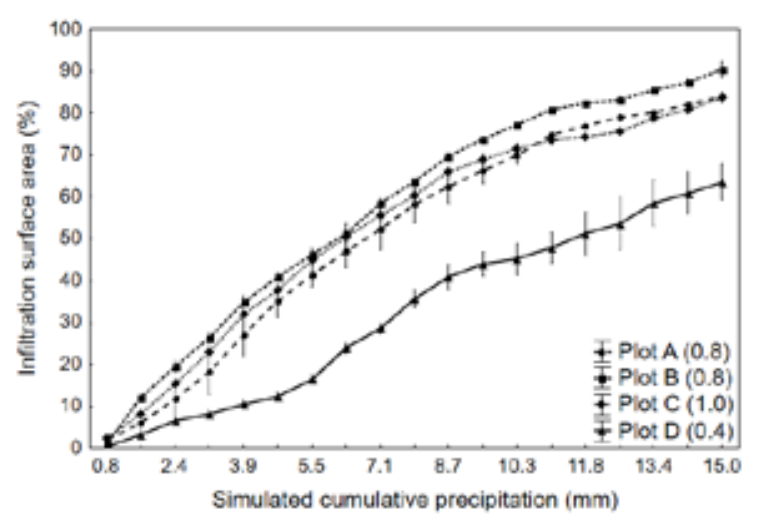

Fig. 4. The growth of infiltration surface area with increasing cumulative precipitation at plots with different stand density.

Statistical tests confirmed a significant effect of the forest stand density on the surface infiltration area (Table 1 and 2). The significant difference between plots with full forest stand density (plots A (0.8), B (0.8), C (1.0)) on one hand and plot $\mathrm{D}(0.4)$ with reduced forest stand density on the other hand was found. In the forest with full stand density, the surface infiltration area at the plot $\mathrm{B}(0.8)$ differed significantly $(p=0.05)$ from the plots A $(0.8)$ and C (1.0). Similarly, statistical tests have confirmed a significant effect of the forest stand density on the number of infiltration inputs (Table 3). The Tukey's post-hoc test confirmed the statistical difference in infiltration inputs at the plot D (0.4) (forest with reduced stand density) from other plots (beech forests with full stand density) (Table 4). Among the plots with full forest stand density, the statistical significant differences in infiltration inputs were not confirmed.

Table 1. Analyses of covariance of infiltration surface area (significance of $F$-tests).

\begin{tabular}{lccccc}
\hline & SS & Degr. of & MS & F & p \\
\hline Intercept & 582,1 & 1 & 582,1 & 8,174 & 0,005 \\
Simulated cumulative & 128414,7 & 1 & 128414,7 & 1803,092 & 0,000 \\
precipitation & & & 4361,5 & 61,241 & 0,000 \\
Forest stand density & 13084,6 & 3 & 71,2 & & \\
Error & 14528,7 & 204 & &
\end{tabular}

Table 2. Tukey HSD post-hoc test of the differences in the infiltration surface area between plots.

\begin{tabular}{lcccc}
\hline Forest nature & Plot A $(0.8)$ & Plot B $(0.8)$ & Plot C $(1.0)$ & Plot D $(0.4)$ \\
\hline Plot A (0.8) & & 0,001439 & 0,780152 & 0,000008 \\
Plot B (0.8) & 0,001439 & & 0,033339 & 0,000008 \\
Plot C (1.0) & 0,780152 & 0,033339 & & 0,000008 \\
Plot D (0.4) & 0,000008 & 0,000008 & 0,000008 & \\
\hline
\end{tabular}

Table 3. Analyses of covariance of infiltration inputs (significance of $F$-tests).

\begin{tabular}{lccccc|}
\hline & SS & Degr. of & MS & F & p \\
\hline Intercept & 12503,24 & 1 & 12503,24 & 359,5763 & 0,000 \\
Simulated cumulative & 978,54 & 1 & 978,54 & 28,1416 & 0,000 \\
infiltration & 2117,13 & 3 & 705,71 & 20,2953 & 0,000 \\
Forest stand density & 7093,52 & 204 & 34,77 & & \\
Error & & & &
\end{tabular}

Table 4. Tukey HSD post-hoc test of the differences in the number of infiltration inputs between plots.

\begin{tabular}{lcccc}
\hline Forest nature & Plot A $(0.8)$ & Plot B $(0.8)$ & Plot C $(1.0)$ & Plot D $(0.4)$ \\
\hline Plot A $(0.8)$ & & 0,999908 & 0,571533 & 0,000008 \\
Plot B $(0.8)$ & 0,999908 & & 0,612186 & 0,000008 \\
Plot C $(1.0)$ & 0,571533 & 0,612186 & & 0,000008 \\
Plot D $(0.4)$ & 0,000008 & 0,000008 & 0,000008 & \\
\hline
\end{tabular}

\section{Discussion}

There exist very few studies dealing with infiltration processes throughout the surface humus and therefore information about soil surface affected by infiltration under forest surface humus is very rare. Campbell et al. (2004) studied infiltration processes by simulated rainfall on slope in the oak forest before and after the removal of surface humus. Significant difference was found only in the topsoil to the depth of $30 \mathrm{~cm}$, in subsoil significant differences were not found.

In our study, we found a clear effect of dense beech regeneration on the increase of infiltration at the plot $\mathrm{A}$ (0.8). The stems of young beech trees form direct infiltration paths, which allow easier infiltration of water from precipitation and stemflows. This finding is in line with Schume et al. (2004). They stated the rainfall water in beech forests preferentially infiltrate near stems. This phenomenon is related mainly to the initial increase in number of infiltration inputs. Subsequent increase in number of infiltration inputs can be caused by saturating of inhomogeneity in surface humus, which does not correspond directly with the position of beech regeneration stems and their activation for infiltration requires higher precipitation. The number of infiltration inputs at the plot B (0.8) is influenced by the internal structure of surface humus, which is mainly composed of beech compact litter. This compact litter layer supported a priority water movement only in the lateral direction and the vertical movement of water is possible only at the places where the interruptions in the compact humus layer exist (therefore fewer inputs infiltration and higher reduction effect of surface humus on infiltration process). Based on the smallest infiltration area we can conclude that each infiltration paths in surface humus allows to infiltrate the same amount of water in fewer infiltration inputs (they are more abundant). At the plot $\mathrm{C}(1.0)$ the number of infiltration inputs is probably affected by the higher number of discontinuities destroy homogeneity of surface humus (e.g. twigs, wild boar activity). The increase in number of infiltration inputs at the plot $\mathrm{D}(0.4)$ is affected by the different surface humus form, where water is infiltrating more downward. The different surface humus form is a 
product of reduction of forest stand density which results in rapid humus decomposition and disruption of compact Oof-humus subhorizon.

No significant differences in infiltration surface area between the plot $\mathrm{A}(0.8)$ and $\mathrm{C}(1.0)$ can be attributed to humus form changes during the forest stage changes. Ponge (2002) also found that more favourable humus forms are in disintegration and ingrowth stage of forest stands which partially corresponds with our plots (plot $\mathrm{A}(0.8)$ is at the beginning of disintegration stage, plot $\mathrm{C}$ (1.0) represents the ingrowth stage). In managed forest (plot D) the surface humus structure has a significant effect on infiltration processes. Pichler (2007) studied how surface humus properties affect retention, accumulation and transformation processes of water and solute in managed forest with different stand density. He found in managed forest under shalterwood cut activation of soil macropore due to surface humus properties (lateral movement of throughfall on short distance). Through these macropores water flows directly into the deeper soil layers, while soil volume affected by infiltrating solute in the upper layers was lower compared to the plot with full stand density. The author also showed that infiltration paths after the dye tracer infiltration tests are typical for macroporous flows. The water flow through macropores in soils under beech forests have been also found by Hümann et al. (2011) and Schume et al. (2003). This macropore preferential flow pathways were formed after coarse roots decay or by mezo- and macro- fauna activities. The macropores in beech forest soils are also very effective drainage system. Through these infiltration processes with synergy of microtopography of soil surface can surface humus support reduction the risk of overland flow (Jost et al. 2012). No overland flow in beech forest was observed also by Hümann et al. (2011) due to higher infiltration capacity and no hydrophobicity of humus layer (surface humus layers were moistened). Infiltration processes of rainfall into the soil affect not only water regime of these soils but also e.g. accumulation and retention of dissolved substances present in the soil solution (Pichler 2007).

Statistically significant effect of reduced forest stand density on the number of infiltration inputs confirms the fact that a complete change of surface humus form is needed to the change of infiltration process. This is confirmed by the fact that on beech plots with full stand density and similar surface humus form the statistically significant differences were not found.

\section{Conclusions}

Our results showed that surface humus form associated with a beech forest stand density has a distinct impact on distribution of rainfall water and infiltration processes in beech forest. Its properties significantly reduce the potential for surface runoff and contribute to the more selective and downward infiltration of water into deeper soil layers. The highest impact was observed in beech stand without a regeneration, where the reduction of infiltration surface area was more than $80 \%$. Plot with very dense beech regeneration and plot in young beech stand showed lower level of reduction in the infiltration surface area. Indicator experiment also showed that the biggest differences among the beech forest stands showed the forest stand with reduced stand density. The higher number of infiltration inputs in forest with reduced stand density do not lead to higher infiltration surface area. The reduction of infiltration surface area was over $70 \%$ despite the differences in surface humus form, surface humus thickness and higher number of infiltration inputs. From this it can be inferred that the regeneration methods based on smallscale shelterwood cut are in stands composed mainly by European beech an appropriate method of regeneration, taking into account the relevant spatial and temporal variability. As prevention to the unproductive surface humus mineralization, it is necessary to take into account the state of the second-growth stand and subsequent final cutting of parent stand performed after eliminating this possibility.

\section{Acknowledgement}

This contribution is the result of the project implementation VEGA 1/0783/15, VEGA 1/0710/17 and APVV-15-0176 supported by the scientific grants awarded by Research and Development Agency.

\section{References}

Ampe, C., Langohr, R., 2003: Morphological characterisation of humus forms in recent coastal dune ecosystems in Belgium and Northern France. Catena, 54:363-383.

Campbell, C. G., Garrido, F., Ghodrati, M., 2004: Role of leaf litter in initiating tracer transport pathways in a woodland hillslope soil. Soil Science, 169:100-114.

Dunkerley, D., 2015: Percolation through leaf litter: What happens during rainfall events of varying intensity? Journal of Hydrology, 525:737-746.

Ewing, R. P., Horton, R., 1999: Discriminating dyes in soil with colour image analysis. Soil Science Society of America Journal, 63:18-24.

Gerrits, A. M. J., Pfister, L., Savenije, H. H. G., 2010: Spatial and temporal variability of canopy and forest floor interception in a beech forest. Hydrological Processes, 24:3011-3025.

Hegg, C., Badoux, A., Lüscher, P., Witzig, J., 2004: Zur Schutzwirkung des Waldes gegen Hochwasser. Forum für das Wissen, p. 15-20.

Hümann, M., Schüler, G., Müller, Ch., Schneider, R., Johst, M., 2011: Identification of runoff processes The impact of different forest types and soil properties on runoff formation and floods. Journal of Hydrology, 409:637-649. 
Jankov, J., Gubka, K., 2013: Analýza povrchového odtoku a erózneho odnosu vo vztahu katmosférickým zrážkam v poraste s pôdoochrannou protieróznou funkciou. Acta Facultatis Forestalis, 55:35-44.

Jost, G., Schume, H., Hager, H., Markart, G., Kohl, B., 2012: A hillslope scale comparison of tree species influence on soil moisture dynamics and runoff processes during intense rainfall. Journal of Hydrology, 420:112-124.

Kantor,P., Šach, F., 2007:Vodnírežim mladého horského smrkového a bukového porostu ve vegetačních obdobích 2005 a 2006. In: Střelcová, K., Škvarenina, J., Blaženec, M. (eds.): Bioclimatology and Natural Hazards. International Scientific Conference, Polana nad Detvou, Slovakia, September $17-20$.

Krečmer, V., 1975: Lesy v ochraně a tvorbě vodních zdrojů. In: Mráček, Z., Krečmer, V.:Význam lesa pro lidskou společnost. SZN, Praha, p. 97-143.

Lapin, M., Faško, P., Melo, M., Štastný, M., Tomlain, J., 2002: Climatic regions. In: Miklós, L. et al. (eds.):The landscape atlas of the Slovak Republic. Ministry of Environment, Bratislava. CD-ROM and DVD.

Matthews, S., 2005: The water vapour conductance of Eucalyptus litter layers. Agricultural and Forest. Meteorology, 135:73-81.

Ogée, J., Brunet, Y., 2002: A forest floor model for heat and moisture including a litter layer. Journal of Hydrology, 255:212-233.

Ottmar, R., Andreu, A., 2007: Litter and duff bulk densities in the Southern United States. Seattle, WA: Fire and Environmental Applications team, USDAForest Service, Joint Fire Science Program Project \#04-2-149. Final Report, $40 \mathrm{p}$.

Pichler, V., 2007: Denzita bukových porastov ako nástroj regulácie hydrických a environmentálnych funkcií pôd. Vedecké štúdie EP 161/2006. Technická univerzita vo Zvolene, $51 \mathrm{p}$.
Ponge, J. F., 1999: Horizons and humus forms in beech forests of the Belgian Ardennes. Soil Science Society of America Journal, 63:1888-1901.

Ponge, J. F., 2002: Humus forms in terrestrial ecosystems: framework to biodiversity. Soil Biology and Biochemistry, 35:935-945.

Qualls, R. G., Haines, B. L., Swank, W. T., Tyler, S. W., 2002: Retention of dissolved organic nutrients by a forested ecosystem. Biogeochemistry, 61:135-171.

Robinson, M., Cognard-Plancq, J., David, P., Durande, H. W., Fuhrer, R., Halla, M. O. et al., 2003: Studies of the impact of forests on peak flows and baseflows: a European perspective. Forest Ecology and Management, 186:85-97.

Schume, H., Jost, G., Katzensteiner, K., 2003: Spatiotemporal analysis of the soil water content in a mixed Norway spruce (Picea abies [L.] Karst.) - European beech (Fagus sylvatica L.) stand. Geoderma, 112:273-287.

Schume, H., Jost, G., Hager, H., 2004: Soil water depletion and recharge patterns in mixed and pure forest stands of European beech and Norway spruce. Journal of Hydrology, 289:258-274.

Shapiro, S. S., Wilk, M. B., 1965: An Analysis of Variance Test for Normality (Complete samples). Biometrika, 52:591-611.

Sokal, R. R., Rohlf, F. J., 1995: Biometry. $3^{\text {rd }}$ Edition, Freeman.

Tukey, J., 1949: Comparing Individual Means in the Analysis of Variance. Biometrics, 5:99-114. JSTOR 3001913.

Valtýni, J., 1985: Vodohospodársky a vodoochranný význam lesa. Bratislava, Príroda, 68 p.

Walsh, R. P. D., Voigt, P. J., 1977: Vegetation litter: An underestimated variable in hydrology and geomorphology, Journal of Biogeography, 4:253-274. 